\title{
SEXUAL ASSAULT: SOCIAL AND STRANGER RAPE
}

\author{
K. EDWARD RENNER \\ Dalhousie University \\ and \\ CAROL WACKETT \\ Service for Sexual Assault Victims
}

\begin{abstract}
The Service for Sexual Assault Victims in Halifax reviewed 474 cases of sexual assault handled ovet a three-year period to determine the nature and relative frequency of social and stranger sexual assault. Women are most likely to be sexually assaulted by a man who is known to and often trusted by them. Women who are raped in a social context are less willing than those raped by a stranger to seek help at the time of the assault, to receive medical attention, or to report the rape to the police. They are also less likely to be threatened with physical harm or to receive physical injury. The cultural values which are responsible for the high frequency of sexual assaults by men who are known to their victims, and for the reluctance of the women to disclose the assault, are discussed.
\end{abstract}

A sexual assault can be either at the hands of a stranger or someone who is known to the victim. The latter is called "acquaintance," "social," or "date" rape. Accurate statistics do not exist on the actual frequency of the two types of rape. Amir (1971) reported $33 \%$ of rape victims knew their assailant, based on 646 cases from the files of the Philadelphia Police Department. An identical estimate was made by the Law Enforcement Assistance Administration (1978) in the U.S. through its national victimization survey. In Canada, similar estimates have been obtained. Clark and Lewis (1977) reported $34 \%$ of 100 cases from the files of the Toronto Police Department were "social" and "acquaintance" rapes; and, the Canadian national victimization study (Solicitor General, 1984) based on interviews of 61,000 households, reported $40 \%$, including $6 \%$ of assaults by relatives.

However, despite these consistent figures from "official" sources, it is generally believed, based primarily on anecdotal information from rape crisis counselors, that social rape is far more frequent than stranger rape and that vic-

Requests for reprints should be sent to: Prof. K. Edward Renner, Department of Psychology, Dalhousie University, Halifax, N.S, B3H 4JI. 
tims of social rape are less likely to report the assault to the police or to seek medical attention (Dowd, 1983; Meyer, 1984; Seligmann, 1984; Shaw, 1985).

Self-report studies have shown that as many as three in 10 college women have been sexually assaulted by their dates (Koss \& Oros, 1982), and as many as four in 10 males self-report some likelihood of raping (Briere \& Malamuth, 1983; Check \& Malamuth, 1983). There is widespread consensus that social rape is a serious problem that has not been adequately acknowledged (Meyer, 1984).

Part of the problem is the widespread cultural acceptance of the belief that forced sex is often acceptable and that the woman is to be blamed for her own assault (Burt, 1980). Many men, and even many women, do not consider unwanted and unasked for sex in a social context as rape. Seligmann (1984) reported that in a 1981 survey of teenagers $54 \%$ of the boys and $42 \%$ of the girls believed forced sexual intercourse was permissible under some circumstances (e.g., "She gets him sexually excited"). A follow-up survey which asked the same questions of college students found $45 \%$ of college males agreed (Mahoney, 1983). In a controlled experiment, Shotland and Goodstein (1983) created several hypothetical scenarios of forced sex in a social context, and found they were not always considered rape if the women showed too much initiative in the relationship, protested too late, and did not resist enough.

Rape counselors report that women who have been raped by an acquaintance have a more difficult time recovering from the effects of the assault because they feel it was their fault (Seligmanm, 1984). They correctly believe that others will blame them (Williams \& Holmes, 1981).

The focus of past research on men who are in prison for violent rape (e.g., Groth, 1979) may also have limited our recognition that sexual assaults frequently occur in the context of "normal" social events (e.g., Shaw, 1985), thus reflecting more about the relationship between men and women in our society than about the psychology of a few deviant individuals (Clark \& Lewis, 1977).

The primary objective of our research was to provide simple descriptive information about the frequency of social as contrasted to stranger sexual assault based on the actual cases that sought assistance from a sexual assault crisis service over a three-year period. A further purpose was to describe some of the differences between social and stranger rape as a means of evaluating the commonly held belief that social rape is a hidden problem (e.g., Meyer, 1984) which presents more difficult adjustment problems for the victim than does rape by a stranger (e.g., Seligmann, 1984).

\section{METHOD}

This report is based on the 474 calls for service received from July, 1983 , through June, 1986, by the Service for Sexual Assault Victims (SSAV) in Halifax. SSAV maintains a record of coded information on each call for service, thus providing a basis for a statistical summary of basic descriptive facts, such as the ages of the victims, types of sexual assault, time of day of the calls, number of contacts, and similar factual variables.

The coded data is a non-selective record of consecutive calls received by SSAV, and thus it is an extraordinary set of information in terms of its breadth. It 
will include, for example, some cases where the victim is still unwilling to reveal her identity in a face-to-face meeting, and the only contact is by telephone. Most often these are cases that never received medical attention and were never reported to the police, thus representing what to date has been an invisible group of victims. However, such data also has many weaknesses, in particular the different amounts of missing information for each case. Because the crisis worker's primary responsibility is to the victim, no information is collected solely for the data file; what is known is what arises through the actions dictated by the crisis intervention protocol.

In addition, the confidential nature of the service provided requires that access to all case material be restricted to those responsible for the administration of SSAV and for the provision of direct service to victims. Thus, the statistical data file contains no personal information, no identity of the victim, nor any case notes or text of any kind; it is simply a numerical code of descriptive information.

\section{RESULTS}

\section{Frequency of Social versus Stranger Sexual Assaults}

When the total of 474 cases in the statistical data file of sexual assaults of women by men are considered, including rape, indecent assault, incest, and child sexual abuse, $82 \%$ of the assaults were by someone known to the victim, including family members. The most frequent place of assault $(55 \%)$ was the victim's own home. In only $18 \%$ of the cases was the assault by a stranger. This is clear evidence that sexual offenses are most properly seen, perhaps even more than ever suspected, as a social rather than a criminal problem from which we can expect police prevention or protection.

When the indecent assault, incest, and child sexual abuse cases were excluded, there were 231 cases of actual rapes (i.e., cases in which a man used force to perform sexual intercourse on a woman). In these cases, $66 \%$ are by someone who is known to the victim through a social context; $34 \%$ are by a stranger. The remaining analysis in this report is restricted to these cases of rape.

\section{The Characteristics of the Victims of Rape}

The majority of the women who were raped were between the ages of 16 and 25 years of age $(52 \%)$, while $17 \%$ were younger and $31 \%$ were older. Most lived on their own, either alone or with a roommate $(50 \%)$, or with their parents $(35 \%)$; only a small number were living in a relationship with a man $(15 \%)$ at the time of the assault. Most victims $(70 \%)$ did not have children, but if they did, they were nearly twice as likely to be a single parent than living as a couple. Onefourth of the victims contacted SSAV within 24 hours of the assault, and $42 \%$ within the first week; one-third of the victims waited more than one year before contacting SSAV.

Thus, the descriptive statistics suggest that the greatest risk of sexual assault is to women who are socially active. Many of them experience long-term emotional consequences as a result of their assault, for which they seek social support only long after the fact, either because no service was available at the time of their assault or because they were unable or unwilling to seek help at the time. 
TABLE 1

Delay in Contacting SSAV by Type of Assault

$\begin{aligned} & \text { Length of Time Between the } \\ & \text { Assault and Contacting SSAV }\end{aligned}$
$\begin{aligned} & \text { During the first week } \\ & \text { after the assault } \\ & \text { Longer than one week } \\ & \text { after the assault } \\ & \text { Assault }\end{aligned}$

TABLE 2

Source of the Call for Service by Type of Assault

Who called SSAV?

The victim or a social

agency for the victim

"Others" including the

police and friends

Totals
Social Sexual Stranger Sexual

Assault

Assault

$58.2 \%$

$36,0 \%$

$42.80^{\circ}$

$64.0 \%$

$100 \%$

$100 \%$

$x^{2}(1, \mathrm{~N}=176)=6.99, p=.008$

\section{The Nature of Social versus Stranger Rape}

Of the women who were the victims of a social rape, most $(59 \%)$ called SSAV a week or more after the assault, and for the majority of these cases the interval between the rape and contacting SSAV was longer than year. In contrast, of the women raped by a stranger, most $(66 \%)$ contacted SSAV in the first week, and the majority did so within the first 24 hours (Table 1). In the case of social rape, the victim or another social agency was the source of referral most of the time $(58 \%)$; whereas in the case of a stranger rape, it was others, including the police and friends, who were most likely $(64 \%)$ to make the call to SSAV (Table 2 ). Thus, there is a clear picture of victims of social rape keeping the information secret for long periods of time and having long-term problems, in contrast with victims of stranger rape who are more likely to receive assistance and attention from others, such as friends and the police, at the time of the assault.

The social rapes represented by this sample were less likely $(28 \%)$ to involve threats of violence or actual physical harm than were stranger rapes $(49 \%)$, although the majority of all rapes took place without threats of physical harm or actual injury (Table 3). The fact that most women, especially in social rape, do not resist a sexual assault to the point of provoking threats of violence or actual physical harm has been considered one source of subsequent feelings of guilt by 


\section{TABLE 3}

Level of Violence by Type of Assault

\begin{tabular}{lcc}
\hline $\begin{array}{l}\text { Level of Violence } \\
\text { Threat of Force }\end{array}$ & $\begin{array}{c}\text { Social Sexual } \\
\text { Assault }\end{array}$ & $\begin{array}{c}\text { Stranger Sexual } \\
\text { Assault }\end{array}$ \\
$\begin{array}{l}\text { Sexual assault without verbal } \\
\text { threats or harm or injury } \\
\begin{array}{l}\text { Threats of violence or actual } \\
\text { physical harm or injury }\end{array}\end{array}$ & $72.4 \%$ & $50.9 \%$ \\
Totals & $27.6 \%$ & $49.1 \%$ \\
$x^{2}(1, \mathrm{~N}=153)=6.25, p=.01$ & $100 \%$ & $100 \%$ \\
\hline
\end{tabular}

\section{TABLE 4}

Percentage of Victims Who Received Medical Attention by Type of Assanlt

\begin{tabular}{lcc}
\hline $\begin{array}{l}\text { Victims Who Received } \\
\text { Medical Attention }\end{array}$ & $\begin{array}{c}\text { Social Sexual } \\
\text { Assault }\end{array}$ & $\begin{array}{c}\text { Stranger Sexual } \\
\text { Assault }\end{array}$ \\
$\begin{array}{l}\text { Did go to the hospital } \\
\text { for medical attention }\end{array}$ & $57.5 \%$ & $76.5 \%$ \\
$\begin{array}{l}\text { Did not go to the hospital } \\
\text { for medical attention }\end{array}$ & $42.5 \%$ & $23.5 \%$ \\
Totals & $100 \%$ & $100 \%$ \\
$x^{2}(1, \mathrm{~N}=131)=4.12, p=.04$ & & \\
\hline
\end{tabular}

the victim and of blame by others, because most people believe a victim would and should risk injury by resisting a sexual assault (Harris \& Parsons, 1985; Renner \& Keith, 1985; Williams \& Holmes, 1981).

Approximately one-half of the victims of social rape did not receive medical attention, nor did they report the offense to the police. In contrast, over threefourths of the victims of stranger rape received medical attention and reported the offense to the police (Tables $4 \& 5$ ). Thus, these findings provide additional indirect evidence that victims of social rape accept more blame and are less comfortable in seeking help or legal recourse than are victims of stranger rape.

\section{DISCUSSION}

The data presented here support the belief that most victims of sexual assault are simply women who are pursuing normal activities for a socially active age group. Similar to other violent crimes against persons, the most likely source of a sexual assault is someone who is known to and often trusted by the victim. The importance of this fact can not be minimized if women are to overcome the social stigma associated with rape and be freed from negative social judgements made by others. 
TABLE 5

Percentage of Victims Who Contacted the Police

by Type of Assault

Victims Who Reported

Assault To The Police

Reported the assault

to the police

Did not report the assault

to the police

Totals

$\begin{array}{cc}\text { Social Sexual } & \text { Stranger Sexual } \\ \text { Assault } & \text { Assault }\end{array}$

$46.1 \%$

$76.9 \%$

$53.9 \%$

$23.1 \%$

$100 \%$

$100 \%$

$x^{2}(1, \mathrm{~N}=141)=11.55, p<.001$

The magnitude of this stigma is dramatically illustrated by the difference between the official estimates that one-third of rapes are by someone known to the victim (Amir, 1971; Clark \& Lewis, 1977; Law Enforcement Assistance Administration, 1978; Solicitor General, 1984), and the experiences of rape crisis centres who see two victims of social rape for every one of stranger rape. There are reasons for suspecting that even this estimate may be too low, because victims of stranger rape are more likely to receive medical and police attention and the sexual assault centre often becomes involved through the initiative of someone other than the victim. One can only assume there is a large invisible population of women who carry in private the residual effects of the betrayal of trust involved in unwanted and unasked for sexual intercourse by an acquaintance or friend through the use of physical force. Clearly, there are many women who will seek assistance long after the time of the assault.

Beyond this personal cost to individual victims, perhaps the issue of greatest social concern is that despite the high percentage of offenders who are known to their victims, rape has been one of the least reported crimes (Solicitor General, 1984), and when reported, one of the least convicted (Renner \& Sahjpaul, 1986; Statistics Canada, 1985). The Federal Provincial Task Force (1983) on justice for victims of crime concluded that victims of rape received poor treatment by the criminal justice system which was in part responsible for their reluctance to disclose their assault. This conclusion was supported by the results of the Canadian victimization study (Solicitor General, 1984) which showed that victims of rape, far more than victims of any other crime, did not expect sympathetic treatment from the police or courts if they reported the offense.

In 1983 Canada modified the criminal code by replacing the offense of rape with the new one of "sexual assault" (Department of Justice, 1983), in part to reduce the stigma of rape and to make it easier for victims to utilize the criminal justice process. Although more victims reported sexual assaults in the first year after the new law was in effect, there was no corresponding improvement by the criminal justice system in the arrest and conviction of offenders (Renner \& Sahjpaul, 1986). In fact, victims who go to court still face a line of questioning by both the defense and prosecution which is more negative and personal than questions asked of victims of other crimes (Sahjpaul \& Renner, 1987). In particular, 
victims of sexual assault are expected to establish that they experienced mental health problems as a result of the assault to have the rape accepted as legitimate by the court (Frazier \& Borgida, 1985; Sahjpaul \& Renner, 1987).

There are important conceptual and practical implications of these facts. Because there is a wide-spread tendency for men to use force to obtain sex, for others to hold women accountable, and for victims to be without effective legal recourse, we must be prepared to accept the feminist interpretation which places sexual assault in a social and cultural context (Herman, 1984). As a result, we can not and should not look primarily to the police as the primary agency to prevent or reduce the incidents of sexual assault. Much more likely sources are our schools and other institutions of social control and socialization which must be prepared to openly address the issues of male-female roles and relationships. The view that we live in a culture that supports rape (Burt, 1980) suggests a more direct connection between sexual assault and family violence, child sexual abuse and pornography, than with psychopathology (i.e., the belief that a few deviant men and "loose" women are the source of the problem).

\section{RESUME}

A Halifax, le Servide d'aide aux victimes de violence sexuelle a fait I'analyse de 474 cas traités durant une période de trois ans; on désirait déterminer la nature et la fréquence relative des assauts perpétrés par une personne connue de la victime et par un étranger. Selon toute vraisemblance les femmes sont assaillies par un homme qu'elles connaissent et en qui elles ont confiance. Par rapport aux femmes assaillies par un étranger, les femmes violées en contexte social sont moins portées à demander de l'aide, à recevoir des soins médicaux, et à faire rapport à la police. Elles sont vraisemblable. ment moins menacées de maux physiques et moins souvent blessées physiquement. On discute des valeurs sous-jacentes à cette fréquence des assauts commis par des hommes connus des victimes et de l'aversion des femmes pour les dénoncer.

\section{REFERENCES}

Amir, M. (1971). Pattern in forcible rape, Chicago: University of Chicago Press.

Briere, J., \& Malamuth, N.M. (1983). Self-reported likelihood of sexually aggressive behavior, Journal of Research in Personality, 17, 315-323.

Burt, M. (1980). Cultural myths and support for rape. Journal of Personality and Social Psychology, 38, 217-230.

Check, J.V., \& Malamuth, N.M. (1983). Sex role stereotyping and reactions to depictions of stranger versus acquaintance rape. Journal of Personality and Social Psychology, 45 , 344-356.

Clark, L.M.G., \& Lewis, D.J. (1977). Rape: The price of coercive sexuality. Toronto: The Women's Press.

Department of Justice. (1983). Sexual assault: The new law, Ottawa: Department of Justice.

Dowd, M. (1983, September 5). Rape: The sexual weapon. Time, 23-25.

Federal-Provincial Task Force. (1983). Justice for victims of crime, Ottawa: Solicitor General of Canada.

Frazier, P., \& Borgida, F. (1985). Rape trauma syndrome evidence in court. American Psychologist, 40, 984-993. 


\section{CANADIAN JOURNAL OF COMMUNITY MENTAL HEALTH}

Groth, A.N. (1979). Men who rape: The psychology of the offender. New York: Plenum Press.

Harris, R.M., \& Parsons, L. (1985). Expected response to assault: The effects of circumstance and locus of control. Canadian Journal of Behavioural Science, 17, 122-129.

Herman, D. (1984). The rape culture, In J. Freeman (Ed.), Women: A feminist perspective (3rd, ed., pp. 20-38). Palo Alto, CA: Mayfield.

Koss, M.P., \& Oros, C.J. (1982). Sexual experiences survey: A research instrument investigating sexual aggression and victimization. Journal of Consulting and Clinical Psychology, 50, 455-457.

Law Enforcement Assistance Administration. (1978). Criminal victimization in the United States. Washington, DC: U.S. Government Printing Office.

Mahoney, E.R. (1983). Human sexuality. New York: McGraw-Hill.

Meyer, T. (1984). Date rape: A serious campus problem that few talk about. Chronicle of Higher Education, 29(15), 1, 12.

Renner, K.E., \& Keith, A. (1985). The establishment of a crisis intervention service for victims of sexual assault. Canadian Journal of Community Mental Health, 4, 113-312.

Renner, K.E., \& Sahjpaul, S, (1986). The new sexual assault law: What has been its effect? Canadian Journal of Criminology, 28, 407-413.

Sahjpaul, S., \& Renner, K.E. (in press). The new sexual assault law: The victim's experience in court. American Joumal of Community Psychology.

Seligmann, J. (1984, April 9). The date who rapes. Newsweek, pp. 91-92.

Shaw, J. (1985, November 5). Date rape: Dirty little social secret. Woman's Day, pp. $88-$ $89 ; 135-137$.

Shotland, R.L., \& Goodstein, L. (1983). Just because she doesn't want to doesn't mean it's rape: An experimentally based causal model of the perception of rape in a dating situation. Social Psychology Quarterly, 46, 220-232.

Solicitor General. (1984). Reported and unreported crimes. Canadian urban victimization survey (Bulletin 2). Ottawa: Solicitor General of Canada.

Statisties Canada. (1985). Crime by offense, 1983. Ottawa: Canadian Centre for Justice Statistics.

Williams, J.E., \& Holmes, K.A. (1981). The second assault: Rape and public attitudes. Westport, CT: Greenwood Press. 